\section{OPEN ACCESS}

Edited by:

Alice Bertaina,

Stanford University, United States

Reviewed by:

Honglin Wang,

Shanghai Jiao Tong University, China

Marcella Franquesa,

Germans Trias i Pujol Health Science

Research Institute (IGTP), Spain

*Correspondence:

Qiuli Liu

liuqli3@mail.sysu.edu.cn

Xiaoyong Chen

cxy-1216@163.com

Specialty section:

This article was submitted to Alloimmunity and Transplantation,

a section of the journal

Frontiers in Immunology

Received: 14 April 2020

Accepted: 09 July 2020

Published: 14 August 2020

Citation:

Liu J, Liu Q and Chen X (2020) The Immunomodulatory Effects of Mesenchymal Stem Cells on Regulatory B Cells.

Front. Immunol. 11:1843. doi: 10.3389/fimmu.2020.01843

\title{
The Immunomodulatory Effects of Mesenchymal Stem Cells on Regulatory B Cells
}

\author{
Jialing Liu ${ }^{1}$, Qiuli Liu ${ }^{1 *}$ and Xiaoyong Chen ${ }^{1,2,3 *}$ \\ ${ }^{1}$ The Biotherapy Center, The Third Affiliated Hospital of Sun Yat-sen University, Guangzhou, China, ${ }^{2}$ Center for Stem Cell \\ Biology and Tissue Engineering, Key Laboratory for Stem Cells and Tissue Engineering, Ministry of Education, Sun Yat-sen \\ University, Guangzhou, China, ${ }^{3}$ Department of Pathophysiology, Zhongshan School of Medicine, Sun Yat-sen University, \\ Guangzhou, China
}

The therapeutic potential of mesenchymal stem cells (MSCs) has been investigated in many preclinical and clinical studies. This potential is dominantly based on the immunosuppressive properties of MSCs. Although the therapeutic profiles of MSC transplantation are still not fully characterized, accumulating evidence has revealed that B cells change after MSC infusion, in particular inducing regulatory B cells (Bregs). The immunosuppressive effects of Bregs have been demonstrated, and these cells are being evaluated as new targets for the treatment of inflammatory diseases. MSCs are capable of educating B cells and inducing regulatory B cell production via cell-to-cell contact, soluble factors, and extracellular vesicles (EVs). These cells thus have the potential to complement each other's immunomodulatory functions, and a combined approach may enable synergistic effects for the treatment of immunological diseases. However, compared with investigations regarding other immune cells, investigations into how MSCs specifically regulate Bregs have been superficial and insufficient. In this review, we discuss the current findings related to the immunomodulatory effects of MSCs on regulatory $B$ cells and provide optimal strategies for applications in immune-related disease treatments.

\begin{abstract}
Keywords: mesenchymal stem cells (MSCs), regulatory B cells (Bregs), cell-to-cell contact, soluble factors, extracellular vesicles (EVs)
\end{abstract}

\section{INTRODUCTION}

Mesenchymal stem cells (MSCs) are multipotent stromal cells existing in many human tissues that can be rapidly expanded in vitro to meet the needs of clinical and basic research. The term MSCs was coined by Caplan in 1991 (1). Since Friedenstein and coworkers demonstrated the osteogenic potential of a minor subpopulation of BM cells that rapid adherence to tissue culture vessels and have a fibroblast-like appearance of their progeny in culture (2), MSCs have been derived from lots of tissues in different species $(3,4)$. However, MSCs still lack specific markers for identification. The International Society for Cell Therapy (ISCT) established three basic criteria for the identification of MSCs in 2006: (1) demonstration of plastic-adherent growth; (2) exhibition of the following phenotypic characteristics: expression of CD105, CD73, and CD90 in more than $95 \%$ of cells; a lack of expression of CD45, CD34, CD14, CD11b, CD79a, and CD19 in the majority of cells; and a lack of expression of HLA-DR; and (3) demonstration of the ability to differentiate into osteoblasts, adipocytes, chondroblasts in vitro (5). MSCs can exhibit important roles in tissue regeneration and repair (6), maintenance of bone marrow hematopoietic microenvironment homeostasis (7), and immunomodulation of inflammation (8). 
Given the current considerable safety and efficacy in preclinical and clinical studies, the roles of MSCs in regenerative medicine have attracted widespread attention, especially their immunomodulatory effects on autoimmune diseases and transplantions, such as Crohn's disease (CD) (9), rheumatoid arthritis (RA) (10), and systemic lupus erythematosus (SLE) (11), as well as graft-versus-host disease (GvHD) (12), kidney transplantation (KTx) $(13,14)$, liver transplantation (LTx) $(15,16)$, chronic lung allograft dysfunction (CLAD) (17) and small bowel transplantation (SBTx) (18), and even their roles in immune-mediated cell therapies (19). MSCs exhibit functional characteristics related to immune regulation and have consistently been shown to play roles in regulating innate and adaptive immune responses via a variety of pathways, such as cell-to-cell contact (20), soluble factors (21), and exosomes derived from MSCs (22). For instance, MSCs possess the ability to secrete regulatory molecules and cytokines that can modulate PBMC maturation, proliferation, differentiation, migration, and functional activation (23-25).

B cells are essential immune effector cells that are pivotal in adaptive immune responses and play roles in autoimmunity through antigen presentation, antibody secretion, and complement activation. Previous studies have shown that MSCs are capable of regulating B cell proliferation and differentiation, inhibiting B cell apoptosis, etc., and they can also suppress the adaptive immune response by indirectly regulating dendritic cell (DC)-mediated antigens. Another mechanism by which MSCs may exert effects on autoimmune diseases in the short and long term is their induction of regulatory B cells (Bregs), especially types that promote the secretion of interleukin (IL)-10, which promote B cells to exhibit immunosuppressive functions and modulate the immune environment homeostasis of patients with autoimmune diseases or solid organ transplantation such kidney transplantation and liver transplantation.

A relatively large number of studies have been published to confirm the clinical phenomenon and mechanisms regarding MSCs regulating regulatory $\mathrm{B}$ cells. In addition, previous studies have shown the regulatory effects in animal disease models and the safety, feasibility and potential effectiveness of allogeneic transplantation of MSCs in clinical trials to treat immune-related diseases. It seems necessary to better understand how the underlying mechanisms of MSC-mediated Breg or combined MSC/Breg cell therapies can be successfully applied in clinical fields. In this review, we discuss MSC functions related to Bregs and the possible mechanisms by which MSCs induce Bregs in vivo and in vitro, especially with regard to IL-10-producing Bregs.

\section{CURRENT DEFINITION AND UNDERSTANDING OF REGULATORY B CELLS}

B cells, an important cells for the adaptive immune response, have the ability to present antigens, secrete antibodies, and activate the immune system (26), which have been observed in autoimmune diseases, infections and cancers. Several subsets of
B cells exert regulatory functions similar to those of regulatory $\mathrm{T}$ cells (Tregs) and are collectively termed regulatory B cells (Bregs). Previous studies have shown that Bregs could inhibit Th1 and Th17 responses and induce $\mathrm{FoxP}_{3}^{+}$Treg pools to play a key role in maintaining peripheral tolerance (27). Regulatory $B$ cells have been found in various B cell subpopulations, including B1 B cells, B2 B cells, and plasma cells (28). Bregmediated immunosuppression is an important manner for the maintenance of peripheral tolerance (29). However, there is still no clear consensus on the definition and classification of Bregs. As their heterogeneity, Bregs may express one or more of regulatory factors [including IL-10, IL-35, transforming growth factor (TGF)- $\beta$, and programmed cell death 1 ligand 1 (PD-L1)] and exert suppressive effects on cognate T cells (27, 30-32). Since three inhibitory cytokines, IL-10, TGF- $\beta$, and IL-35, having been identified as key inhibitory inflammatory factors for Bregs, Bregs can be divided into three categories: IL- $10^{+}, \mathrm{TGF}-\beta^{+}$, and IL$35^{+}$Bregs. Among these, the IL- $10^{+}$Bregs, also called B10 cells, are the major cell type in mediating immunosuppression. IL-10 ${ }^{+}$ Bregs have been widely regarded as important immunoregulatory cells in various inflammatory diseases, such as RA (33), chronic intestinal inflammatory conditions (34), SLE (35), CD (36), Collagen Induced Arthritis (CIA) (37), and GVHD (38). Besides, Bregs also play an important role in transplantation, including KTx $(39,40)$, cardiac allografts (41), liver transplantation (42) and so on. The various subpopulation phenotypes among IL-10 ${ }^{+}$ Bregs are shown in Table $\mathbf{1}$.

The term "regulatory B cells" were firstly introduce by Bhan and Mizoguchi. Using T-cell receptor (TCR)- $\alpha^{-/-}$mice, $\mu \mathrm{MT}$ mice, and TCR- $\alpha^{-/-} \mu \mathrm{MT}$ mice, they found that colitis pathogenesis does not require B cells, but B cells are presumably involved in the elimination of apoptotic cells, which contributed to suppressing colitis (60). Similarly, Michael Hahne et al. reported that LPS-activated B cells expressing FAS ligands (FasL) can clear activated $\mathrm{T}$ cells such as FAS-expressing $\mathrm{T}$ cells, and transfer of LPS-activated B cells could ameliorate the development of diabetes in NOD mice (61). Subsequently, Atsushi Mizoguchi et al. found that under conditions of chronic enteritis, B cell subsets, characterized by upregulation of CD1d expression, can produce IL-10 and attenuate IL-1 upregulation and signal transducer and activator of transcription (STAT) 3 activation, which indicates that B cells producing IL10 could serve as regulatory cells in immunologically mediated inflammatory responses (34). Later, Claudia Mauri et al. used agonistic anti-CD40 and collagen to stimulate arthritic B cells, increasing the secretion of IL-10 in B cell subsets to control the proinflammatory Th1 type response while reducing secretion of interferon (IFN)- $\gamma$; the findings proved that these B cells play important roles in immune regulation in arthritis models (33). Niamh E. Mangan et al. have also reported that the induction of IL-10-producing $\mathrm{B}$ cells can modulate allergic responses in worm-infected mice $(62,63)$. Besides, studies of Bregs in transplantation have also been conducted. Lal Girdhari et al. proved that CD40 costimulatory blockade induces IL-10 producing Marginal Zone Precursor (MZP) Bregs, especially IL$21 \mathrm{R}^{+}$MZP Bregs, performing a key function in restoring graft survival (50). 
TABLE 1 | Phenotypes of IL-10+ Bregs.

\begin{tabular}{|c|c|c|}
\hline Species & Phenotype & Function \\
\hline \multirow[t]{9}{*}{ Mouse } & CD138high (43) & Anti-Salmonella immunity \\
\hline & CD19+CD5+CD1 digh $(44,45)$ & $\begin{array}{l}\text { Treg induction; inhibition of Th17 } \\
\text { response }\end{array}$ \\
\hline & CD1d ${ }^{\text {high }} C D 23^{\text {high }}$ CD21 $1^{\text {int }}(46)$ & Protective role in the mucosa \\
\hline & $\begin{array}{l}\mathrm{CD} 19^{+} \mathrm{CD} 43^{+} \mathrm{CD} 80^{+} \mathrm{CD} 86^{+} \mathrm{CD} 40^{+} \\
(47)\end{array}$ & Inhibition of Th1 response \\
\hline & $\mathrm{CD}_{19}+\mathrm{CD} 43^{+} \mathrm{CD}^{+}(48)$ & Amelioration of CGVHD \\
\hline & CD1d high (49) & Treg induction \\
\hline & $\mathrm{CD} 5^{+} \mathrm{CD} 1 \mathrm{~d}^{\mathrm{hi}}(41)$ & $\begin{array}{l}\text { Inhibition of Th1 cells activation; } \\
\text { induction of islet allograft } \\
\text { tolerance }\end{array}$ \\
\hline & CD19+CD24 high CD38 high (30) & $\begin{array}{l}\text { Suppression of Th1 cell } \\
\text { differentiation }\end{array}$ \\
\hline & $\mathrm{IL}-21 \mathrm{R}^{+} \mathrm{MZP}(50)$ & $\begin{array}{l}\text { Induction transplantation } \\
\text { tolerance }\end{array}$ \\
\hline \multirow[t]{9}{*}{ Human } & $\mathrm{CD}^{+} \mathrm{IL}-10^{+}(51)$ & Inhibition of Th1 response \\
\hline & $\begin{array}{l}\mathrm{CD} 19^{+} \mathrm{CD} 25^{\text {high }} \mathrm{CD} 27^{\text {high }} \\
\text { CD86 } \\
\text { (52) }\end{array}$ & $\begin{array}{l}\text { Suppression of CD4+ T cell } \\
\text { proliferation }\end{array}$ \\
\hline & $\begin{array}{l}\mathrm{CD} 19^{+} \mathrm{CD} 38^{+} \mathrm{CD}_{1 \mathrm{~d}^{+}} \operatorname{lgM}^{+} \mathrm{CD} 147^{+} \\
\mathrm{CD} 25^{+}(53)\end{array}$ & $\begin{array}{l}\text { Suppression of antitumor } \\
\text { immune responses }\end{array}$ \\
\hline & CD24high $C D 27^{+}(42,54)$ & $\begin{array}{l}\text { Negatively regulate monocyte } \\
\text { cytokine production; predicted } \\
\text { the occurrence of acute allograft } \\
\text { rejection in liver transplantation }\end{array}$ \\
\hline & $\mathrm{CD}_{154^{+}}(55)$ & A character of SLE patients \\
\hline & $\mathrm{CD} 25^{+} \mathrm{CD} 71^{+} \mathrm{CD} 73^{\text {low }} \mathrm{PD}-\mathrm{L}^{+}{ }^{+}(56)$ & $\begin{array}{l}\text { Suppress antigen-specific } \\
\text { immune responses }\end{array}$ \\
\hline & $\mathrm{CD} 27^{\text {int }} \mathrm{CD} 38^{+}(57)$ & Production of IL-10 \\
\hline & CD5 $5^{\text {high }} C D 38^{\text {low }}$ PD-1 $1^{\text {high }}(58)$ & $\begin{array}{l}\text { Inhibition of Th1 and Th17 } \\
\text { differentiation }\end{array}$ \\
\hline & $\mathrm{CD}_{23}{ }^{+} \mathrm{CD} 43^{+}(59)$ & Inhibition of $\mathrm{T}$ cell response \\
\hline
\end{tabular}

\section{MSCS PLAY ANTI-INFLAMMATORY ROLES IN IMMUNE DISEASES BY INCREASING BREGS}

There have been many discoveries shown that MSCs exert immunomodulatory functions to affect B cells. In 2006, Anna Corcione et al. first discovered that hMSCs can directly interact with $\mathrm{B}$ cells to prevent their proliferation and death while promoting arrest during the G0-G1 phase of the cell cycle. They found that the expression of CXCR4, CXCR5, and CCR7 in B cells was downregulated as a result of inhibition of human B cell proliferation, differentiation into antibodysecreting cells, and chemotaxis in vitro (64). In 2007, Patrizia Comoli et al. reported MSCs induced by allo-stimulation in vitro are capable of modulating B-cell allo-responses via inhibiting antibody production, suggesting that third-party MSCs are able to suppress allo-specific antibody production in vitro, and may therefore help overcome a positive cross-match in sensitized transplant recipients (65). In 2009, it was reported that MSCs inhibit B cell terminal differentiation by releasing cytokines to downregulate B cell Blimp-1 expression both in vitro and in vivo (66). Moreover, Elisabetta Traggiai et al., through polyclonal stimulation of B cells isolated from children with systemic lupus erythematosus and healthy donors, found that bone marrow MSCs can promote the proliferation of transitional cells and naive $\mathrm{B}$ cells and their differentiation into immunoglobulin-secreting cells, moreover, MSCs strongly promote the proliferation of memory $\mathrm{B}$ cells and their differentiation into plasma cells (67).

Many previous studies have focused on MSCs inducing the production of regulatory $\mathrm{T}$ cells to exert immunosuppressive functions. Similarly, the modulation of regulatory B cells by MSCs also plays important roles in the treatment of many diseases. For example, in experimental autoimmune encephalomyelitis (EAE), an experimental model of human multiple sclerosis (MS), $\mathrm{CD} 1 \mathrm{~d}^{\text {high }} \mathrm{CD}^{+}$regulatory B cells were upregulated after MSC administration and exert antiinflammatory and immunosuppressive effects (68). Experiments have also found that human umbilical cord MSCs (hUCMSCs) protect experimental mice by increasing the numbers of $\mathrm{CD}^{+}$Bregs that produce IL-10 and correcting Treg/Th17/Th1 imbalance in a colitis model (69). Furthermore, Y Peng et al. have reported that the numbers of $\mathrm{CD}^{+} \mathrm{IL}-10^{+}$regulatory $\mathrm{B}$ cell subset are increased in patients with refractory chronic graft-versus-host disease after MSC treatment (70). Minglu Yan et al. reported that human synovial membrane-derived MSCs can inhibit the maturation and differentiation of $\mathrm{B}$ cells; induce $\mathrm{CD} 21^{\text {high }} \mathrm{CD} 23^{\text {high }}$ transitional 2 (T2) cells, CD23 ${ }^{\text {low }} \mathrm{CD} 21^{\text {high }}$

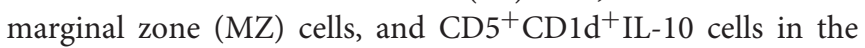
spleen; and increase the numbers of immature transitional B cells, such as $\mathrm{IL}-10^{+}$cells, thus reducing the severity of arthritis in mice (71). Kunal S. Gupte et al. reported that co-culture of adipose tissue-derived MSCs (AD-MSCs) from 15 potential kidney donors with peripheral blood PBMCs could induce IL-10-secreting B cells, demonstrating the promise of cell therapies for immune diseases after transplantation (72). Studies demonstrated that MSC infusions contributed to long-term stabilization of renal allograft function, likely via triggering an active peripheral immunomodulation to induce long term immunophenotyping of naïve and $\mathrm{CD} 24^{\text {high }} \mathrm{CD} 38^{\text {high }}$ transitional B-cell subsets in kidney allograft recipients (73). Along with this, another recent study held by Davide Piloni el at. proved that $\mathrm{CD} 19^{+} \mathrm{CD} 24^{\text {high }} \mathrm{CD} 38^{\text {high }}$ Breg cell subset also showed key functions in the long term acceptance of lung graft (74). These discoveries of B-cell subsets provide not only a potential marker of MSC-induced immunomodulation associated with transplantation tolerance, but also a prospective view in IL-10 producing B cells key functions among SOT applications. Recently, Di Lu et al. found that allogeneic MSC transplantation can promote the levels of IL-4 and IL-10 and the induction of Bregs in an aGVHD mouse model with complete mismatch of MHC and significantly inhibit the expression of CD69 and CD86 on B lymphocytes to prolong survival, thus demonstrating that $\mathrm{B}$ lymphocytes play an important role in the development of aGVHD and that B lymphocytes are targets of the immune regulatory cascade in MSCs (75). Studies based in vitro experiments or preclinical and clinical researches have 
TABLE 2 | Summary of the studies on MSC-mediated effects to Bregs.

\begin{tabular}{|c|c|c|}
\hline Study & Disease or study type & Key findings \\
\hline Chen et al. (76) & Clinical trial: BOS after allo-HSCT & Increased CD5 ${ }^{+} \mathrm{B}$ cells and IL-10-producing CD19+ CD5 ${ }^{+}$Bregs \\
\hline Chen et al. (59) & Colitis model & Induced the novel CD23+CD43+Bregs subset \\
\hline Planella et al. (77) & Invitro study & The PF as well as the CM could increase induced CD24 ${ }^{\text {high }} C D 38^{\text {high }} B$ cells \\
\hline Lu et al. (75) & Acute GVHD model & Decreased IL-4 and increased IL-10+Bregs \\
\hline Li et al. (78) & EAE model & Increased $\mathrm{CD}^{+} \mathrm{IL}-10^{+} \mathrm{B}$ cells \\
\hline Mehdipour et al. (79) & Invitro study & Decreased TNF- $\alpha^{+} / \mathrm{IL}-10^{+} \mathrm{B}$ cells ratio in B cell-ASCs co-culture \\
\hline Luk et al. (80) & Invitro study & $\begin{array}{l}\text { Under immunological quiescent conditions, MSC increased IL }-10^{+} \text {CD } 38^{\text {high }} \text { CD } 24^{\text {high }} \\
\text { Bregs }\end{array}$ \\
\hline Yan et al. (71) & ClA model & $\begin{array}{l}\text { Increased CD2 } 1^{\text {high }} \mathrm{CD} 23^{\text {high }} \mathrm{T} 2 \text { cells, CD23 }{ }^{\text {low }} \mathrm{CD} 21^{\text {high }} \mathrm{MZ} \text { cells, and } \\
\mathrm{CD} 5^{+} \mathrm{CD} 1 \mathrm{~d}^{+} \mathrm{IL}-10^{+} \text {Bregs }\end{array}$ \\
\hline Gupte et al. (72) & Invitro study & Increased IL-10-secreting Bregs from baseline of patients \\
\hline Cho et al. (81) & Animal in-vivo study & Induced IL-10-expressing Bregs in an EBI3-dependent manner \\
\hline Zhang et al. (82) & Clinical trial: NS after allo-HSCT & Induced CD19+ $\mathrm{CD}^{+} \mathrm{IL}-10^{+}$Bregs \\
\hline Hermankova et al. (83) & Invitro study & $\begin{array}{l}\text { IFN- } \gamma \text {-treated MSCs inhibited IL-10 production by activated B cells via cell-contact and } \\
\text { the Cox- } 2 \text { pathway }\end{array}$ \\
\hline Chao et al. (69) & Colitis model & Boosted the numbers of CD5+ $\mathrm{B}$ cells and IL-10-producing CD5+ Bregs \\
\hline Peng et al. (70) & Clinical trial: refractory cGvHD & Increased IL-10-producing CD5+ B cells \\
\hline Franquesa et al. (84) & Invitro study & $\begin{array}{l}\text { Reduced plasmablast formation and induce IL-10-producing CD19+CD24 }{ }^{\text {high }} \text { CD } 38^{\text {high }} \\
\text { Bregs }\end{array}$ \\
\hline Park et al. (85) & SLE model & Increased IL-10-producing Bregs \\
\hline Garimella et al. (86) & ClA model & Increased the CD19 ${ }^{+} \mathrm{CD} 1 \mathrm{~d}^{\text {high }} \mathrm{CD}^{+}$Bregs in the spleens of ASC-treated CIA mice \\
\hline Wang et al. (87) & Cardiac allograft model & MSC-expressing B7-H1 neutralization reduced IL-4 ${ }^{\text {high }} \mathrm{IL}-10^{\text {high }} \mathrm{CD} 83^{\text {low }} \mathrm{B}$ cells \\
\hline Guo et al. (68) & EAE model & Upregulated CD1d ${ }^{\text {high }}$ CD5 ${ }^{+}$Bregs \\
\hline
\end{tabular}

BOS, Bronchiolitis obliterans syndrome; HSCT, Hematopoietic Stem Cell Transplantation; GVHD, graft-versus-host disease; EAE, experimental autoimmune encephalomyelitis; CIA, collagen-induced arthritis; NS, Nephrotic syndrome; SLE, systemic lupus erythematosus.

reported the induction of Bregs by MSCs as we summarized in Table 2.

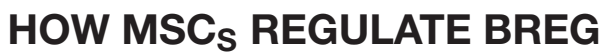 GENERATION}

Accumulating evidence has revealed the importance of Bregs and Tregs in the maintenance of immune tolerance, and MSCmediate disease improvements are often associated with the induction of Bregs and Tregs. It's well-known that MSCs regulate Tregs proliferation, survival, and function mainly through several pathways. Firstly, cell-to-cell contact, through which interactions among different molecules expressed by MSCs and T lymphocytes (such as ICOSL and ICOS, Notch and Notch ligands), upregulates the production of IL-10 and the proliferation of Tregs. Followed, the secretion of soluble factors by MSCs, including TGF $\beta$, CCL2, IL-6, IL-7, PGE2, IDO, HO-1, and HLA-G5, can regulate Treg generation (88-90). Moreover, antigen-presenting cell dependence; in this pathway, MSCs affect antigen-presenting cells (dendritic cells, monocytes, macrophages) to induce regulatory phenotypes and promote Treg activity through IL-10 and TGF- $\beta 1$, although the detailed mechanism has not been fully elucidated. In addition, MSCderived extracellular vesicles, containing specific RNA, proteins and other biological molecules, induce the polarization of $\mathrm{CD} 4^{+}$ T cell into Tregs (91).
Compared to MSCs inducing Tregs, the specific mechanisms by which MSCs regulate the generation of Breg are still not sufficiently clear. Several studies have focus on the mechanism that induces the generation of Bregs. $\mathrm{H} \mathrm{Li}$ et al. found that $\mathrm{T}$ follicular regulatory (Tfr) cells could induce IL- $10^{+}$Breg cells, as higher frequency of IL- $10^{+}$Breg cells was observed when incubation with Tfr cells (92). Moreover, tolerogenic DC (tolDC), one type of DC with immuno-suppressive properties, were reported to induce the IL-10 producing Breg, as wells as the IL-10 producing type 1 regulatory T cells (Tr1) (93). Cynthia M. Fehres et al. described that a proliferation-inducing ligand (APRIL) induced $\mathrm{IL}-10^{+} \mathrm{B}$ cells production in EAE and CHS models, as APRIL promoted the differentiation of naïve human $B$ cells to IL-10-producing $\operatorname{IgA}^{+} \mathrm{B}$ cells (94). It has been postulated by some investigators that the conditions in the microenvironment are key factors for the induction of Bregs. Notably, Toll-like receptor (TLR), CD40, and BCR-induced signaling are vital for Breg function (95-97). In view of previous studies that have assessed multiple modulatory mechanisms of MSCs, we illustrate below the relationship between MSCs and Bregs from several perspectives, which also summarized in the Figure $\mathbf{1}$.

\section{Cell-to-Cell Contact}

MSCs can regulate immune responses through direct cell-to-cell contact. Via interaction with surface molecules and/or receptors, MSCs might directly regulate their downstream pathways in $B$ cells, thereby affecting $B$ cell activation, proliferation, 


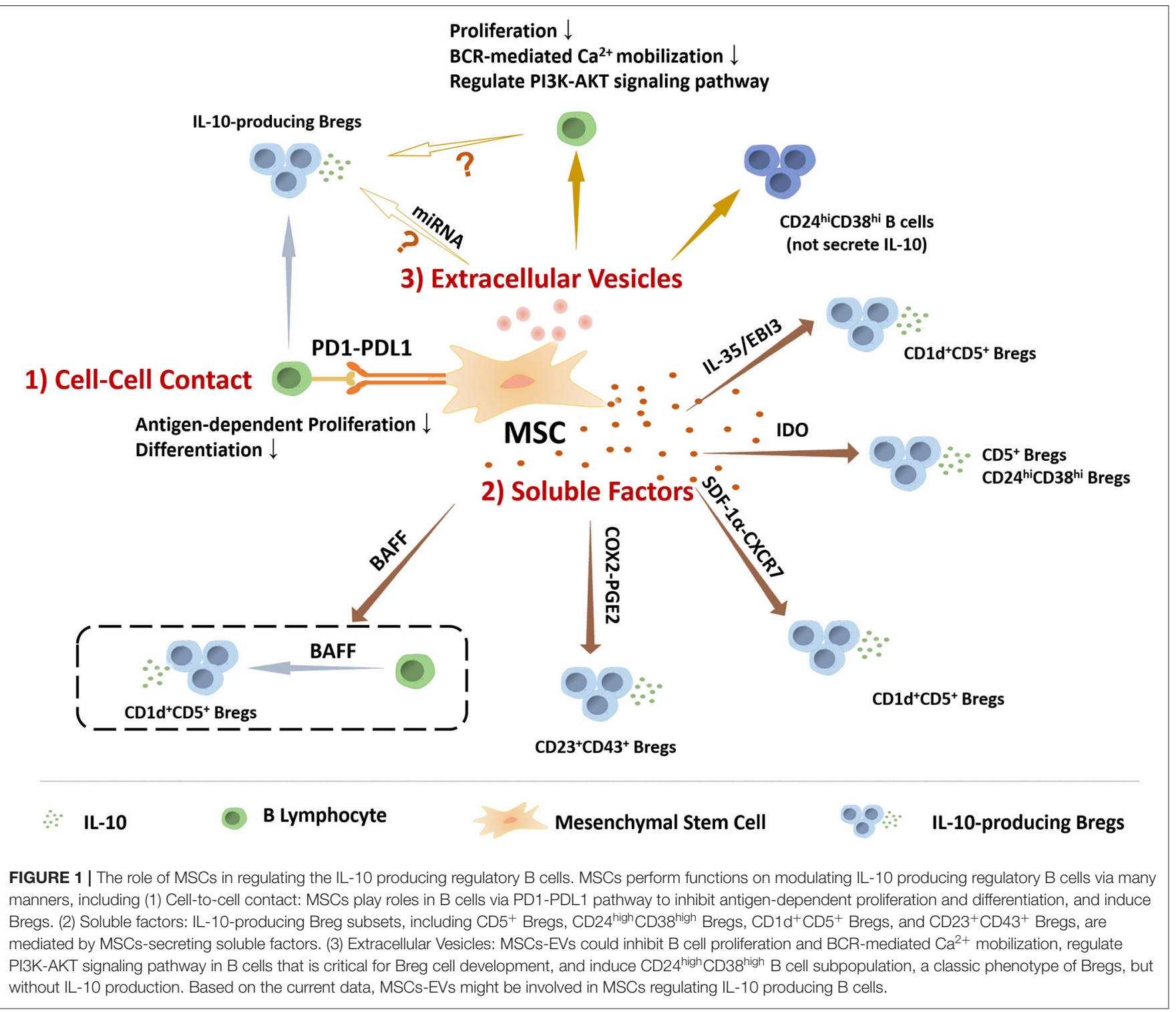

survival, differentiation, and Bregs induction. For instance, M. Franquesa et al. experimentally demonstrated that hASCs can act independently of $\mathrm{T}$ cells and directly on B cells to promote the production of $\mathrm{CD} 19^{+} \mathrm{CD} 24^{\text {high }} \mathrm{CD} 38^{\text {high }}$ and IL-10-production regulatory B cells (84). Although cell-to-cell contact manner have been confirmed to be involved in MSCs inducing Bregs by the transwell co-culture $(59,80)$, little is known about the particular molecules. One of the major molecules involved in this cellto-cell interaction of MSCs is the costimulatory molecules is programmed death ligand-1 (PD-L1, also known as B7-H1). PDL1 is well-known for its role in immune checkpoint regulation (98). Its receptor, programmed cell death protein 1 (PDCD1; also known as PD1), is an immunoglobulin-superfamily member that over-expressed upon programmed cell death as its primary function described to attenuate the immune response (99, 100). Francesca Schena et al. found that BM-MSCs inhibit antigen-dependent proliferation and differentiation of follicle and $\mathrm{MZ} \mathrm{B}$ cells in vitro through the $\mathrm{PD}-1 / \mathrm{PD}-\mathrm{L} 1$ pathway, and ameliorate the inflammatory response in systemic lupus erythematosus mice (101). $\mathrm{H}$ Wang et al. reported that the expression of B7-H1 on MSCs was required for IL-10-producing Bregs development in recipients and MSC-mediated suppression of antibody production and B cell proliferation, which contribute to the induction of immune tolerance to allografts in mouse cardiac allograft model by the combination therapy of MSCs and rapamycin (RAPA) (87).

\section{Soluble Molecule Interactions Cyclooxygenase-2 (COX-2)/PGE2}

Prostaglandins (PGs) are small molecule derivatives of arachidonic acid produced by cyclooxygenase (102). Prostaglandin E2 (PGE2), the main product of cyclooxygenase in myeloid cells and stromal cells, is a biologically active factor whose synthesis was regulated by COX-2 and shown to regulate 
multiple aspects of inflammation in immune cells (103). Many studies have shown that MSCs exert their therapeutic ability mainly dependent on PGE2 secretion (104, 105). MSCs-derived PGE2 also contribute to their induction of Tregs (106). In B cells, Tae-Hoon Shin et al. show that COX-2 signals are necessary for MSCs to inhibit the proliferation and maturation of B lymphocytes, result of inhibiting the secretion of IgE by mature $B$ cells in a mouse atopic dermatitis (AD) model (107). R Chen et al. shown that PGE2 could induce B10 cells via the MAPKs/AKT-AP1 axis or aryl hydrocarbon receptor (AhR) signaling (108). Recently, COX-2/PGE2 pathway is also found to involved in MSCs induce $\mathrm{CD} 23^{+} \mathrm{CD} 43^{+}$Bregs, which significantly reducing the clinical and histopathological severity of induced colon inflammation and ameliorating gastrointestinal mucosal tissue damage in mice (59). However, IFN- $\gamma$-primed MSCs were reported to inhibit the production of IL-10 by LPS-activated B cells through the COX-2 pathway (83). PGE2 has shown to exert paradoxes function in regulating immune response (103), more experiments might need to uncover the key mechanisms and targets of PGE2-mediated effects on MSCs inducing Bregs. The immune status of MSCs may be another cause needed pay attention to, as the microenvironment is one of the major factors that affecting the immuno-regulatory ability of MSCs.

\section{Indolamine-2,3-dioxygenase (IDO)}

IDO catalyzes the first and rate-limiting step of tryptophan catabolism in the kynurenine pathway, and its downstream metabolites include kynurenine (KYN) and 3-hydroxyanthranilic acid. It is worth noting that IDO has been shown to regulate the expression of inflammation-related genes, either by itself as a signaling factor or through the production of biologically active intermediates via the kynurenine pathway, such as 3hydroxyanthranilic acid and kynurenic acid (KYNA). IDO could inhibited $\mathrm{T}$ cell proliferation and modulated regulatory $\mathrm{T}$ cell differentiation $(109,110)$. G Wang et al. demonstrated IDO is necessary to the therapeutic effects of human umbilical cord-derived MSC (hUC-MSC) for treating acute lung injury (ALI) (111). Based on previous studies, the IDO expression in MSCs require priming by IFN- $\gamma$ and pro-inflammatory cytokines that enhance IDO levels via JAK/STAT signaling $(112,113)$. IFN- $\gamma$-pretreated MSCs inhibit the production of IgG and the proliferation of $\mathrm{B}$ cells, largely dependent on tryptophan catabolism by IDO (80). Human umbilical cord-derived MSCs (hUC-MSCs) can control EAE by increasing the proportion and promoting the function of $\mathrm{CD}^{+} \mathrm{IL}^{-10^{+}} \mathrm{B}$ cells. After co-culture with MSCs, $\mathrm{CD}^{+} \mathrm{B}$ cells show a stronger ability to inhibit $\mathrm{T}$ cell proliferation and proimmflamatory cytokines secretion, as well as to induce Tregs (78), and these enhanced immunomodulation of $\mathrm{CD}^{+} \mathrm{B}$ cells by MSCs were reversed when blocking the IDO pathway. Moreover, MSCs increased the frequency of $\mathrm{CD} 5^{+}$Breg cells by enhancing their proliferation and survival via the IDO pathway (70).

\section{IL-35}

Interleukin-35 is a novel anti-inflammatory cytokine belonging to the IL-12 cytokine family that can be applied as a potential therapy for chronic inflammation and autoimmune diseases (114). Human IL-35, which functions as an important immunomodulator, seems to inhibit mature inflammation rather than prevent inflammation as IL-35 is not constitutively expressed in human tissue $(27,115,116)$. IL-35 has reported to induce both Tregs and Bregs (117). IL-35 could induce the conversion of $\mathrm{B}$ cells into Bregs, including IL- $35^{+}$Bregs and IL- $10^{+}$Bregs. Mice deficient in p35 or EBI3, the two subunits of IL-35, exhibit an exacerbation in EAE and experimental autoimmune uveitis (EAU) with less Bregs $(27,43)$. Studies have revealed that overexpression of IL-35 in hMSCs can increase the proportion of Tregs among lamina propria lymphocytes (LPLs) and induce an immunosuppressive microenvironment via inhibition of the expression of TNF- $\alpha$, IFN- $\gamma$, and IL-17 in the lamina propria (114). Similarly, IL-35 also takes part in MSCs inducing Bregs. Kyung-Ah Cho et al. have proven that MSCs are capable of ameliorating B-cell activation induced by hormonal stimulation, and directly inducing the population of immunosuppressive IL10-secreting Breg cells in an IL-35-dependent manner without acting on T cells; both these MSCs-mediated effects require MSCs-derived EBI3, a critical subunit of IL-35 (81).

\section{SDF- $1 \alpha-C X C R 7$}

Stromal cell-derived factor- $1 \alpha$ (SDF- $1 \alpha$, also known as CXCL12) is a crucial process involved in the chemotaxis of stem cells/progenitor cells (118). Previous studies have reported that the migration and survival of MSCs have been enhanced via up-regulation of SDF-1 receptors, CXCR4 and CXCR7, under hypoxic preconditioning stimulation, which likely contribute to improving the therapeutic effect in renal ischemia/reperfusion (I/R) injury in animal model (119). According to Marie-Luise Humpert et al. research, CXCR7, is an atypical chemokine receptor, binds CXCL12 and CXCL11 to regulate CXCR4/SDF-1mediated the migration of plasmablasts during B-cell maturation (120). Moreover, Yan Qin et al. demonstrated that low concentration of SDF-1 promoted MSCs to induce IL-10producing Bregs while high concentrated inhibited MSCs induction of $\mathrm{IL}-10^{+}$Breg cells, but overexpressed CXCR7 of MSCs can reverse this inhibitory effect. The result supported that SDF-1 $\alpha$-CXCR7 axis play key roles in MSCs regulating IL-10-producing Bregs, especially $\mathrm{CD} 1 \mathrm{~d}^{+} \mathrm{CD} 5^{+} \mathrm{IL}-10^{+}$Bregs, by regulating paracrine actions (121). In addition, endometrial regenerative cells (ERCs), mesenchymal-like stromal cells, have been found to induce a donor-specific allograft tolerance in mouse cardiac allograft models, which is depended on SDF-1 mediated increasing levels of regulatory immune cells including IL-10 producing CD $1 d^{\text {high }} \mathrm{CD} 5^{\text {high }} \mathrm{CD} 83^{\text {low }}$ Bregs (122).

\section{B Cell-Activating Factor (BAFF)}

$B$ cell-activating factor (BAFF) is a member of the tumor necrosis factor superfamily known to play a critical role in the survival and maturation of B cells by binding to the receptors BCMA (B cell maturation antigen) and TACI (transmembrane activator and CAML interactor) (123). BAFF is also critical for naive circulating $\mathrm{B}$ cell and MZ B cell homeostasis. BAFF is expressed in a wide variety of cell types, including macrophages, dendritic cells and neutrophils, and even functions in an autocrine manner (124). 
Using BAFF-transgenic (Tg) mice, BAFF has been demonstrated to induce $\mathrm{CD}^{+}{ }^{+}$Foxp $3^{+}$Treg cells to suppress T-cell responses (125), suggesting a regulatory role of BAFF in vivo. Followed, low dosages of BAFF was found to possess the ability to induce IL-10 producing Bregs with the phenotype of $\mathrm{CD} 1 \mathrm{~d}^{\text {hi }} \mathrm{CD} 5^{+}$, moreover, the number of IL-10-producing B cells in the marginal zone regions were increased when treated with BAFF in vivo (126). Interestingly, MSCs were reported to express BAFF both in mRNA and protein (127), indicating that MSCs might have the ability to induce Bregs via secreting BAFF. In clinical studies, MSCs are shown to decrease the plasma levels of BAFF in patients with cGVHD or refractory rheumatoid arthritis (RA), accompanied with regulating the activity of $\mathrm{B}$ cells and alteration in B cell subpopulation $(128,129)$. However, more experiments still need to confirm the BAFF-mediated effects on MSCs inducing Bregs, and reveal the underling mechanisms.

\section{MSC-EVs}

An increasing number of studies have shown that MSCs perform many paracrine functions by releasing extracellular vesicles (EVs). In particular, small EVs (50-200 nm in diameter) (130) can be obtained from cell culture supernatants of MSCs cultured under different culture conditions and have been reported to possess therapeutic effects in different preclinical models. MSC-derived exosomes function through horizontal transfer of proteins, mRNA, and regulatory microRNAs (131). MSC-EVs have become promising therapeutic agents (132). Drirh Khare et al. identified 39 upregulated genes by sequencing exosomes derived from MSCs cocultured with B cells, including SerpinB2, PTGS2, CXCL8 (IL8), and MZB1 (marginal zone B and B1 cell specific protein) (133-136). These genes are involved in a variety of classic immunosuppressive effects, including inhibition of $\mathrm{T}$ cell activation, $\mathrm{B}$ cell proliferation, and BCR-mediated $\mathrm{Ca}^{2+}$ mobilization, proving that mesenchymal stromal cell exosomes affect the expression and function of B lymphocytes (137). Recently, L Guo et al. reported that MSC-EVs prevent fibrosis of skin in sclerodermatous cGVHD mouse model via blocking the TFH/GC B cells interaction and reduce the ratio of BAFF to B cells in vivo (138). MSC-derived soluble protein-enriched fractions (MSC-PFs) have effects comparable to those of MSCs and can promote $\mathrm{B}$ cells to produce IL-10. MSC-EVs induce $\mathrm{CD} 24^{\text {high }} \mathrm{CD} 38^{\text {high }} \mathrm{B}$ cells to the same extent as MSCs while the resulting cells do not produce IL-10 (77). MiR-155, a microRNA that significant increase in MSCs prime with IFN- $\gamma$ and TNF$\alpha$ (139), promotes IL-10 production in $\mathrm{CD} 24^{\mathrm{hi}} \mathrm{CD} 27^{+}$Bregs directly by inhibiting the expression of Jarid2, resulting in reduction of H3K27me3 binding to the IL10 promoter (139). In addition, MSCs-EVs are found to regulate the PI3K-AKT signaling pathway in B cells (140), combined with PI3K-Akt pathway in B cells is critical for Breg cell development, it is conceivable that MSCs might regulate the Bregs via their EVs to modulate the PI3K-AKT signaling pathway in B cells. Of course, there are still many unknowns in this field, and more research is needed to uncover the role of MSCs-EV in regulating Bregs.

Nevertheless, the potential for MSC-EVs immunomodulation remains promising, although the mechanisms of MSC-EVs in Breg induction is not yet well-understood. Moreover,
MSC-EVs are traditionally derived from highly heterogeneous MSC cells. Due to the diversity of MSCs, the complexity of MSCs preparation, the lack of standardized quality assurance procedures for various methods of production and isolation of EVs, and the limited reproducibility of in vitro and in vivo functional assays. Four associations (SOCRATES, ISEV, ISCT, and ISBT) have proposed specific harmonized standards for MSC-EV preparation, which will help promote the development of clinical applications in this field (141).

\section{CONCLUSIONS}

Investigations in the past few years have provided new insights into the functions of MSCs in immune system modulation and the potential of MSC-based cell therapies, which have been extensively assessed in clinical studies for their efficacy in degenerative, autoimmune, or inflammatory diseases. The mechanisms by which MSCs perform their therapeutic functions are multifaceted, but in general, these cells are thought to be able to balance the inflammatory and regenerative microenvironment of damaged tissue in the presence of severe inflammation. Studies on the interactions between immune systems and MSCs have shown that enhancement of the immunoregulatory activity of MSCs is essential during tissue regeneration. Over past decades, numerous studies have been conducted to clarify the immunomodulatory effects of MSCs on immune cells. Completed and ongoing clinical trials and in vivo studies on the therapeutic effects of MSCs against immune-mediated diseases have proven that MSCs can increase the generation of Bregs. It has been suggested that MSCs can increase the secretion of IL-10 by Bregs to treat inflammatory diseases, but research on specific mechanisms is still relatively scarce. Undeniably, the effectiveness of related B cell-based treatments greatly depends on the functions of Bregs, especially IL-10secreting Bregs. Numerous studies on Bregs have revealed that B10 cells have powerful potential to ameliorate inflammatory disorders, exhibiting promise for use in the treatment of autoimmune diseases. On the one hand, regulatory B cells have not been clearly defined, and there is a lack of identified markers. At present, Bregs are still defined on the basis of their functions, which make breakthroughs in related research difficult. We have reviewed previous studies on effective MSCmediated promotion of the production of $\mathrm{IL}-10^{+}$Bregs. To a certain extent, MSCs have multiplicative potential; they are able to induce Bregs and/or increase Breg production through a wide range of verified direct and indirect mechanisms. In the future, further studies are needed to discover reliable markers for defining different subpopulations of Bregs, clarify the heterogeneity among different subpopulations of Bregs used in specific treatments and clarify the potential mechanisms by which MSCs regulate Bregs. In clinical applications of MSCs combined with Bregs for the treatment of immune diseases, the stability and flexibility of the treatments should be closely considered and optimized to achieve appropriate modulation of inflammatory responses at different stages of disease progression. 


\section{AUTHOR CONTRIBUTIONS}

JL and XC searched the literature and wrote the manuscript. XC and QL critically revised the manuscript and final approval of the work. All authors contributed to the article and approved the submitted version.

\section{FUNDING}

This work was supported by the National Key Research and Development Program of China, Stem Cell and Translational

\section{REFERENCES}

1. Caplan AI. Mesenchymal stem cells. J Orthopaedic Res. (1991) 9:641-50. doi: 10.1002 /jor.1100090504

2. Friedenstein AJ, Chailakhjan RK, Lalykina KS. The development of fibroblast colonies in monolayer cultures of guinea-pig bone marrow and spleen cells. Cell Tissue kinet. (1970) 3:393-403. doi: 10.1111/j.1365-2184.1970.tb00347.x

3. Hass R, Kasper C, Böhm S, Jacobs R. Different populations and sources of human mesenchymal stem cells (MSC): a comparison of adult and neonatal tissue-derived MSC. Cell Commun Signal. (2011) 9:12. doi: 10.1186/1478-811X-9-12

4. Owen M, Friedenstein AJ. Stromal stem cells: marrow-derived osteogenic precursors. Ciba Found Symp. (1988) 136:42-60. doi: 10.1002/9780470513637.ch4

5. Dominici M, Le Blanc K, Mueller I, Slaper-Cortenbach I, Marini F, Krause D, et al. Minimal criteria for defining multipotent mesenchymal stromal cells. the International society for cellular therapy position statement. Cytotherapy. (2006) 8:315-7. doi: 10.1080/14653240600855905

6. Hatzistergos KE, Quevedo H, Oskouei BN, Hu Q, Feigenbaum GS, Margitich IS, et al. Bone marrow mesenchymal stem cells stimulate cardiac stem cell proliferation and differentiation. Circ Res. (2010) 107:913-22. doi: 10.1161/CIRCRESAHA.110.222703

7. Crippa S, Bernardo ME. Mesenchymal stromal cells: role in the BM niche and in the support of hematopoietic stem cell transplantation. HemaSphere. (2018) 2:e151. doi: 10.1097/HS9.0000000000000151

8. Bernardo ME, Fibbe WE. Mesenchymal stromal cells: sensors and switchers of inflammation. Cell Stem Cell. (2013) 13:392-402. doi: 10.1016/j.stem.2013.09.006

9. Ciccocioppo R, Bernardo ME, Sgarella A, Maccario R, Avanzini MA, Ubezio C, et al. Autologous bone marrow-derived mesenchymal stromal cells in the treatment of fistulising Crohn's disease. Gut. (2011) 60:788-98. doi: 10.1136/gut.2010.214841

10. Li R, Zhang Y, Zheng X, Peng S, Yuan K, Zhang X, et al. Synergistic suppression of autoimmune arthritis through concurrent treatment with tolerogenic DC and MSC. Sci Rep. (2017) 7:43188. doi: 10.1038/srep 43188

11. Wang D, Wang S, Huang S, Zhang Z, Yuan X, Feng X, et al. Serum IFN$\gamma$ predicts the therapeutic effect of mesenchymal stem cells transplantation in systemic lupus erythematosus patients. Stem Cell Transl Med. (2017) 6:1777-85. doi: 10.1002/sctm.17-0002

12. Morata-Tarifa C, Macías-Sánchez MDM, Gutiérrez-Pizarraya A, SanchezPernaute R. Mesenchymal stromal cells for the prophylaxis and treatment of graft-versus-host disease-a meta-analysis. Stem Cell Res Ther. (2020) 11:64. doi: 10.1186/s13287-020-01592-z

13. Perico N, Casiraghi F, Remuzzi G. Clinical translation of mesenchymal stromal cell therapies in nephrology. J Am Soc Nephrol. (2018) 29:362-75. doi: 10.1681/ASN.2017070781

14. Reinders MEJ, van Kooten C, Rabelink TJ, de Fijter JW. Mesenchymal stromal cell therapy for solid organ transplantation. Transplantation. (2018) 102:35-43. doi: 10.1097/TP.0000000000001879

15. Vandermeulen M, Gregoire C, Briquet A, Lechanteur C, Beguin Y, Detry O. Rationale for the potential use of mesenchymal stromal cells
Research (2018YFA0107203 and 2017YFA010550), the National Natural Science Foundation of China $(81971526,81970109$, 31771616, 81730005, and 81760112), Guangdong Basic and Applied Basic Research Foundation (2020A1515010272), the Key Scientific and Technological Projects of Guangdong Province (2019B020236004, 2019B020234001, 2019B020235002, and 2017B020230004), Key Scientific and Technological Program of Guangzhou City (201803040011 and 201802020023), Pearl River S\&T Nova Program of Guangzhou (201906010095), and Fundamental Research Funds for the Central Universities (20ykpy149). in liver transplantation. World J Gastroenterol. (2014) 20:16418-32. doi: 10.3748/wjg.v20.i44.16418

16. Detry O, Vandermeulen M, Delbouille MH, Somja J, Bletard N, Briquet $\mathrm{A}$, et al. Infusion of mesenchymal stromal cells after deceased liver transplantation: a phase I-II, open-label, clinical study. J Hepatol. (2017) 67:47-55. doi: 10.1016/j.jhep.2017.03.001

17. Keller CA, Gonwa TA, Hodge DO, Hei DJ, Centanni JM, Zubair AC. Feasibility, safety, and tolerance of mesenchymal stem cell therapy for obstructive chronic lung allograft dysfunction. Stem Cells Transl Med. (2018) 7:161-7. doi: 10.1002/sctm.17-0198

18. Ceresa CD, Ramcharan RN, Friend PJ, Vaidya A. Mesenchymal stromal cells promote bowel regeneration after intestinal transplantation: myth to mucosa. Transpl Int. (2013) 26:e91-3. doi: 10.1111/tri.12139

19. Shi Y, Wang Y, Li Q, Liu K, Hou J, Shao C, et al. Immunoregulatory mechanisms of mesenchymal stem and stromal cells in inflammatory diseases. Nat Rev Nephrol. (2018) 14:493-507. doi: 10.1038/s41581-018-0023-5

20. Sheng $H$, Wang $Y$, Jin $Y$, Zhang Q, Zhang $Y$, Wang L, et al. A critical role of IFNgamma in priming MSC-mediated suppression of $\mathrm{T}$ cell proliferation through up-regulation of B7-H1. Cell Res. (2008) 18:846-57. doi: $10.1038 /$ cr.2008.80

21. Spaggiari GM, Capobianco A, Abdelrazik H, Becchetti F, Mingari MC, Moretta L. Mesenchymal stem cells inhibit natural killer-cell proliferation, cytotoxicity, and cytokine production: role of indoleamine 2,3-dioxygenase and prostaglandin E2. Blood. (2008) 111:1327-33. doi: 10.1182/blood-2007-02-074997

22. Nargesi AA, Lerman LO, Eirin A. Mesenchymal stem cell-derived extracellular vesicles for renal repair. Curr Gene Ther. (2017) 17:29-42. doi: $10.2174 / 1566523217666170412110724$

23. Di Nicola M, Carlo-Stella C, Magni M, Milanesi M, Longoni PD, Matteucci P, et al. Human bone marrow stromal cells suppress T-lymphocyte proliferation induced by cellular or nonspecific mitogenic stimuli. Blood. (2002) 99:383843. doi: 10.1182/blood.V99.10.3838

24. Gazdic M, Volarevic V, Arsenijevic N, Stojkovic M. Mesenchymal stem cells: a friend or foe in immune-mediated diseases. Stem Cell Rev Rep. (2015) 11:280-7. doi: 10.1007/s12015-014-9583-3

25. Vizoso FJ, Eiro N, Cid S, Schneider J, Perez-Fernandez R. Mesenchymal stem cell secretome: toward cell-free therapeutic strategies in regenerative medicine. Int J Mol Sci. (2017) 18:1852. doi: 10.3390/ijms18091852

26. Boothby M, Rickert RC. Metabolic regulation of the immune humoral response. Immunity. (2017) 46:743-55. doi: 10.1016/j.immuni.2017.04.009

27. Wang RX, Yu CR, Dambuza IM, Mahdi RM, Dolinska MB, Sergeev YV, et al. Interleukin-35 induces regulatory B cells that suppress autoimmune disease. Nat Med. (2014) 20:633-41. doi: 10.1038/nm.3554

28. Baba Y, Saito Y, Kotetsu Y. Heterogeneous subsets of B-lineage regulatory cells (Breg cells). Int Immunol. (2020) 32:155-62. doi: 10.1093/intimm/dxz068

29. Mauri C, Ehrenstein MR. The 'short' history of regulatory B cells. Trends Immunol. (2008) 29:34-40. doi: 10.1016/j.it.2007.10.004

30. Blair PA, Noreña LY, Flores-Borja F, Rawlings DJ, Isenberg DA, Ehrenstein MR, et al. CD19+CD24hiCD38hi B cells exhibit regulatory capacity in healthy individuals but are functionally impaired in 
systemic lupus erythematosus patients. Immunity. (2010) 32:129-40. doi: 10.1016/j.immuni.2009.11.009

31. Guan H, Wan Y, Lan J, Wang Q, Wang Z, Li Y, et al. PD-L1 is a critical mediator of regulatory B cells and T cells in invasive breast cancer. Sci Rep. (2016) 6:35651. doi: 10.1038/srep35651

32. Lee KM, Stott RT, Zhao G, SooHoo J, Xiong W, Lian MM, et al. TGF- $\beta$-producing regulatory $\mathrm{B}$ cells induce regulatory $\mathrm{T}$ cells and promote transplantation tolerance. Eur J Immunol. (2014) 44:1728-36. doi: 10.1002/eji.201344062

33. Mauri C, Gray D, Mushtaq N, Londei M. Prevention of arthritis by interleukin 10-producing B cells. J Exp Med. (2003) 197:489-501. doi: 10.1084/jem.20021293

34. Mizoguchi A, Mizoguchi E, Takedatsu H, Blumberg RS, Bhan AK. Chronic intestinal inflammatory condition generates IL-10-producing regulatory $\mathrm{B}$ cell subset characterized by CD1d upregulation. Immunity. (2002) 16:21930. doi: 10.1016/S1074-7613(02)00274-1

35. Yu M, Song $\mathrm{Y}$, Zhu M-X, Liang $\mathrm{W}$, Long $\mathrm{Q}$, Ding $\mathrm{P}-\mathrm{W}$, et al. B10 cells ameliorate the progression of lupus nephritis by attenuating glomerular endothelial cell injury. Cell Physiol Biochem. (2015) 36:2161-9. doi: $10.1159 / 000430182$

36. Zheng Y, Ge W, Ma Y, Xie G, Wang W, Han L, et al. miR-155 regulates IL-10-producing CD24(hi)CD27(+) B cells and impairs their function in patients with crohn's disease. Front Immunol. (2017) 8:914. doi: 10.3389/fimmu.2017.00914

37. Yang $\mathrm{M}$, Deng J, Liu Y, Ko, K-H, Wang X, Jiao Z, et al. IL-10producing regulatory B10 cells ameliorate collagen-induced arthritis via suppressing Th17 cell generation. Am J Pathol. (2012) 180:2375-85. doi: 10.1016/j.ajpath.2012.03.010

38. Chakupurakal G, Garcia-Marquez MA, Shimabukuro-Vornhagen A, Kluth S, Schlosser H, Theurich S, et al. Regulatory B10 cells display an altered homoeostasis in acute graft-versus-host disease. Eur J Haematol. (2017) 98:128-33. doi: 10.1111/ejh.12810

39. Rebollo-Mesa I, Nova-Lamperti E, Mobillo P, Runglall M, Christakoudi S, Norris S, et al. Biomarkers of tolerance in kidney transplantation: are we predicting tolerance or response to immunosuppressive treatment? Am J Transplant. (2016) 16:3443-57. doi: 10.1111/ajt.13932

40. Pallier A, Hillion S, Danger R, Giral M, Racapé M, Degauque N, et al. Patients with drug-free long-term graft function display increased numbers of peripheral B cells with a memory and inhibitory phenotype. Kidney Int. (2010) 78:503-13. doi: 10.1038/ki.2010.162

41. Qin $\mathrm{Y}$, Zhang $\mathrm{M}$, Jiang R-M, Wu Q, Xu X-Y, Chen H, et al. B10 cells play a role in the immune modulation of pro- and anti-inflammatory immune responses in mouse islet allograft rejection. Cell Immunol. (2016) 310:18492. doi: 10.1016/j.cellimm.2016.09.010

42. Zhou H, Zhan F, Zhang H, Gu J, Mu X, Gao J, et al. The proportion of CD19(+)CD24(hi)CD27(+) regulatory B cells predicts the occurrence of acute allograft rejection in liver transplantation. Ann Transl Med. (2019) 7:465. doi: 10.21037/atm.2019.08.05

43. Shen P, Roch T, Lampropoulou V, O'Connor RA, Stervbo U, Hilgenberg E, et al. IL-35-producing B cells are critical regulators of immunity during autoimmune and infectious diseases. Nature. (2014) 507:366-70. doi: $10.1038 /$ nature 12979

44. Xing C, Ma N, Xiao $\mathrm{H}$, Wang $\mathrm{X}$, Zheng $\mathrm{M}$, Han $\mathrm{G}$, et al. Critical role for thymic CD19+CD5+CD1dhilL-10+ regulatory B cells in immune homeostasis. J Leukoc Biol. (2015) 97:547-56. doi: 10.1189/jlb.3A0414-213RR

45. Zhang $M$, Zheng $X$, Zhang J, Zhu Y, Zhu X, Liu $H$, et al. $\mathrm{CD} 19+\mathrm{CD} 1 \mathrm{~d}+\mathrm{CD} 5+\mathrm{B}$ cell frequencies are increased in patients with tuberculosis and suppress Th17 responses. Cell Immunol. (2012) 274:89-97. doi: 10.1016/j.cellimm.2012.01.007

46. Dalwadi H, Wei B, Schrage M, Spicher K, Su TT, Birnbaumer L, et al. B cell developmental requirement for the $\mathrm{G} \alpha$ i2 gene. J Immunol. (2003) 170:1707-15. doi: 10.4049/jimmunol.170.4.1707

47. Mann MK, Maresz K, Shriver LP, Tan Y, Dittel BN. B cell regulation of $\mathrm{CD} 4+\mathrm{CD} 25+\mathrm{T}$ regulatory cells and IL-10 via $\mathrm{B} 7$ is essential for recovery from experimental autoimmune encephalomyelitis. J Immunol. (2007) 178:3447-56. doi: 10.4049/jimmunol.178. 6.3447
48. Moins-Teisserenc H, Busson M, Herda A, Apete S, Peffault de Latour R, Robin M, et al. CD19+CD5+ B cells and B1-like cells following allogeneic hematopoietic stem cell transplantation. Biol Blood Marrow Transplant. (2013) 19:988-91. doi: 10.1016/j.bbmt.2013.03.006

49. van der Vlugt LEPM, Labuda LA, Ozir-Fazalalikhan A, Lievers E, Gloudemans AK, Liu K-Y, et al. Schistosomes induce regulatory features in human and mouse $\mathrm{CD} 1 \mathrm{~d}(\mathrm{hi}) \mathrm{B}$ cells: inhibition of allergic inflammation by IL-10 and regulatory T cells. PLoS ONE. (2012) 7:e30883. doi: 10.1371/journal.pone. 0030883

50. Lal G, Nakayama Y, Sethi A, Singh AK, Burrell BE, Kulkarni N, et al. Interleukin-10 from marginal zone precursor B-cell subset is required for costimulatory blockade-induced transplantation tolerance. Transplantation. (2015) 99:1817-28. doi: 10.1097/TP.0000000000000718

51. Lee JH, Noh J, Noh G, Choi WS, Lee SS. IL-10 is predominantly produced by $\mathrm{CD} 19(\mathrm{low}) \mathrm{CD} 5(+)$ regulatory B cell subpopulation: characterisation of CD19 (high) and CD19(low) subpopulations of CD5(+) B cells. Yonsei Med J. (2011) 52:851-5. doi: 10.3349/ymj.2011.52.5.851

52. Kessel A, Haj T, Peri R, Snir A, Melamed D, Sabo E, et al. Human $\mathrm{CD} 19(+) \mathrm{CD} 25$ (high) B regulatory cells suppress proliferation of CD4(+) $\mathrm{T}$ cells and enhance Foxp3 and CTLA-4 expression in T-regulatory cells. Autoimmun Rev. (2012) 11:670-7. doi: 10.1016/j.autrev.2011.11.018

53. Lindner S, Dahlke K, Sontheimer K, Hagn M, Kaltenmeier C, Barth TFE, et al. Interleukin 21-induced granzyme B-expressing B cells infiltrate tumors and regulate T cells. Cancer Res. (2013) 73:2468-Z79. doi: 10.1158/0008-5472.CAN-12-3450

54. Iwata Y, Matsushita T, Horikawa M, Dilillo DJ, Yanaba K, Venturi GM, et al. Characterization of a rare IL-10-competent B-cell subset in humans that parallels mouse regulatory B10 cells. Blood. (2011) 117:530-41. doi: 10.1182/blood-2010-07-294249

55. Díaz-Alderete A, Crispin JC, Vargas-Rojas MI, Alcocer-Varela J. IL10 production in B cells is confined to CD154+ cells in patients with systemic lupus erythematosus. J Autoimmun. (2004) 23:379-83. doi: 10.1016/j.jaut.2004.10.001

56. van de Veen W, Stanic B, Yaman G, Wawrzyniak M, Söllner S, Akdis DG, et al. IgG4 production is confined to human IL-10-producing regulatory B cells that suppress antigen-specific immune responses. J Allergy Clin Immunol. (2013) 131:1204-12. doi: 10.1016/j.jaci.2013.01.014

57. Matsumoto M, Baba A, Yokota T, Nishikawa H, Ohkawa Y, Kayama $\mathrm{H}$, et al. Interleukin-10-producing plasmablasts exert regulatory function in autoimmune inflammation. Immunity. (2014) 41:1040-51. doi: 10.1016/j.immuni.2014.10.016

58. Flores-Borja F, Bosma A, Ng D, Reddy V, Ehrenstein MR, Isenberg DA, et al. CD19+CD24hiCD38hi B cells maintain regulatory T cells while limiting TH1 and TH17 differentiation. Sci Transl Med. (2013) 5:173ra123. doi: 10.1126/scitranslmed.3005407

59. Chen X, Cai C, Xu D, Liu Q, Zheng S, Liu L, et al. Human mesenchymal stem cell-treated regulatory $\mathrm{CD} 23(+) \mathrm{CD} 43(+) \mathrm{B}$ cells alleviate intestinal inflammation. Theranostics. (2019) 9:4633-47. doi: 10.7150/thno.32260

60. Mizoguchi A, Mizoguchi E, Smith RN, Preffer FI, Bhan AK. Suppressive role of B cells in chronic colitis of T cell receptor alpha mutant mice. J Exp Med. (1997) 186:1749-56. doi: 10.1084/jem.186.10.1749

61. Hahne M, Renno T, Schroeter M, Irmler M, French L, Bornard T, et al. Activated B cells express functional Fas ligand. Eur J Immunol. (1996) 26:721-4. doi: $10.1002 /$ eji.1830260332

62. Mangan NE, Fallon RE, Smith P, van Rooijen N, McKenzie AN, Fallon PG. Helminth infection protects mice from anaphylaxis via IL-10-producing B cells. J Immunol. (2004) 173:6346-56. doi: 10.4049/jimmunol.173.10.6346

63. Lenert P, Brummel R, Field EH, Ashman RF. TLR-9 activation of marginal zone $\mathrm{B}$ cells in lupus mice regulates immunity through increased IL-10 production. J Clin Immunol. (2005) 25:29-40. doi: 10.1007/s10875-005-0355-6

64. Corcione A, Benvenuto F, Ferretti E, Giunti D, Cappiello V, Cazzanti F, et al. Human mesenchymal stem cells modulate B-cell functions. Blood. (2006) 107:367-72. doi: 10.1182/blood-2005-07-2657

65. Comoli P, Ginevri F, Maccario R, Avanzini MA, Marconi M, Groff A, et al. Human mesenchymal stem cells inhibit antibody production induced in vitro by allostimulation. Nephrol Dial Transplant. (2007) 23:1196-202. doi: $10.1093 / \mathrm{ndt} / \mathrm{gfm} 740$ 
66. Asari S, Itakura S, Ferreri K, Liu CP, Kuroda Y, Kandeel F, et al. Mesenchymal stem cells suppress B-cell terminal differentiation. Exp Hematol. (2009) 37:604-15. doi: 10.1016/j.exphem.2009.01.005

67. Traggiai E, Volpi S, Schena F, Gattorno M, Ferlito F, Moretta L, et al. Bone marrow-derived mesenchymal stem cells induce both polyclonal expansion and differentiation of B cells isolated from healthy donors and systemic lupus erythematosus patients. Stem Cells. (2008) 26:562-9. doi: 10.1634/stemcells.2007-0528

68. Guo Y, Chan KH, Lai WH, Siu CW, Kwan SC, Tse HF, et al. Human mesenchymal stem cells upregulate $\mathrm{CD} 1 \mathrm{dCD} 5(+)$ regulatory $\mathrm{B}$ cells in experimental autoimmune encephalomyelitis. Neuroimmunomodulation. (2013) 20:294-303. doi: 10.1159/000351450

69. Chao K, Zhang S, Qiu Y, Chen X, Zhang X, Cai C, et al. Human umbilical cord-derived mesenchymal stem cells protect against experimental colitis via CD5(+) B regulatory cells. Stem Cell Res Ther. (2016) 7:109. doi: 10.1186/s13287-016-0376-2

70. Peng Y, Chen X, Liu Q, Zhang X, Huang K, Liu L, et al. Mesenchymal stromal cells infusions improve refractory chronic graft versus host disease through an increase of CD5+ regulatory B cells producing interleukin 10. Leukemia. (2015) 29:636-46. doi: 10.1038/leu.2014.225

71. Yan $\mathrm{M}$, Liu $\mathrm{X}$, Dang $\mathrm{Q}$, Huang $\mathrm{H}$, Yang $\mathrm{F}$, Li $\mathrm{Y}$. Intra-articular injection of human synovial membrane-derived mesenchymal stem cells in murine collagen-induced arthritis: assessment of immunomodulatory capacity in vivo. Stem Cells Int. (2017) 2017:9198328. doi: 10.1155/2017/ 9198328

72. Gupte KS, Vanikar AV, Trivedi HL, Patel CN, Patel JV. In-vitro generation of interleukin-10 secreting B-regulatory cells from donor adipose tissue derived mesenchymal stem cells and recipient peripheral blood mononuclear cells for potential cell therapy. Biomed J. (2017) 40:49-54. doi: $10.1016 /$ j.bj.2017.01.003

73. Perico N, Casiraghi F, Todeschini M, Cortinovis M, Gotti E, Portalupi V, et al. Long-term clinical and immunological profile of kidney transplant patients given mesenchymal stromal cell immunotherapy. Front Immunol. (2018) 9:1359. doi: $10.3389 /$ fimmu.2018.01359

74. Piloni D, Morosini M, Magni S, Balderacchi A, Inghilleri S, Cova E, et al. Peripheral CD19+CD24highCD38high B-regulatory cells in lung transplant recipients. Transplant Immunol. (2019) 57:101245. doi: 10.1016/j.trim.2019.101245

75. Lu D, Ma T, Zhou X, Jiang Y, Han Y, Li H. B lymphocytes are the target of mesenchymal stem cells immunoregulatory effect in a murine graft-versus-host disease model. Cell Transplant. (2019) 28:1279-88. doi: 10.1177/0963689719860127

76. Chen S, Zhao K, Lin R, Wang S, Fan Z, Huang F, et al. The efficacy of mesenchymal stem cells in bronchiolitis obliterans syndrome after allogeneic HSCT: a multicenter prospective cohort study. EBioMedicine. (2019) 49:21322. doi: 10.1016/j.ebiom.2019.09.039

77. Carreras-Planella L, Monguio-Tortajada M, Borras FE, Franquesa M. Immunomodulatory effect of MSC on B cells is independent of secreted extracellular vesicles. Front Immunol. (2019) 10:1288. doi: 10.3389/fimmu.2019.02413

78. Li H, Deng Y, Liang J, Huang F, Qiu W, Zhang M, et al. Mesenchymal stromal cells attenuate multiple sclerosis via IDO-dependent increasing the suppressive proportion of CD5+ IL-10+ B cells. Am J Transl Res. (2019) 11:5673-88.

79. Mehdipour F, Razmkhah M, Rezaeifard S, Bagheri M, Talei AR, Khalatbari B, et al. Mesenchymal stem cells induced anti-inflammatory features in B cells from breast tumor draining lymph nodes. Cell Biol Int. (2018) 42:1658-69. doi: $10.1002 /$ cbin. 11062

80. Luk F, Carreras-Planella L, Korevaar SS, de Witte SFH, Borràs FE, Betjes $\mathrm{MGH}$, et al. Inflammatory conditions dictate the effect of mesenchymal stem or stromal cells on B cell function. Front Immunol. (2017) 8:1042. doi: 10.3389/fimmu.2017.01042

81. Cho K-A, Lee J-K, Kim Y-H, Park M, Woo S-Y, Ryu K-H. Mesenchymal stem cells ameliorate B-cell-mediated immune responses and increase IL10-expressing regulatory B cells in an EBI3-dependent manner. Cell Mol Immunol. (2017) 14:895-908. doi: 10.1038/cmi.2016.59

82. Zhang X, Peng Y, Fan Z, Zhao K, Chen X, Lin R, et al. Mesenchymal stem cells may ameliorate nephrotic syndrome post-allogeneic hematopoietic stem cell transplantation-case report. Front Immunol. (2017) 8:962. doi: 10.3389/fimmu.2017.00962

83. Hermankova B, Zajicova A, Javorkova E, Chudickova M, Trosan P, Hajkova $\mathrm{M}$, et al. Suppression of IL-10 production by activated B cells via a cell contact-dependent cyclooxygenase-2 pathway upregulated in IFNgamma-treated mesenchymal stem cells. Immunobiology. (2016) 221:129-36. doi: 10.1016/j.imbio.2015.09.017

84. Franquesa M, Mensah FK, Huizinga R, Strini T, Boon L, Lombardo E, et al. Human adipose tissue-derived mesenchymal stem cells abrogate plasmablast formation and induce regulatory B cells independently of T helper cells. Stem Cell. (2015) 33:880-91. doi: 10.1002/stem.1881

85. Park M-J, Kwok S-K, Lee S-H, Kim E-K, Park S-H, Cho M-L, et al. Adipose tissue-derived mesenchymal stem cells induce expansion of interleukin-10producing regulatory B cells and ameliorate autoimmunity in a murine model of systemic lupus erythematosus. Cell Transplant. (2015) 24:2367-77. doi: 10.3727/096368914X685645

86. Garimella MG, Kour S, Piprode V, Mittal M, Kumar A, Rani L, et al. Adipose-derived mesenchymal stem cells prevent systemic bone loss in collagen-induced arthritis. J Immunol. (2015) 195:5136-48. doi: 10.4049/jimmunol.1500332

87. Wang H, Qi F, Dai X, Tian W, Liu T, Han H, et al. Requirement of B7$\mathrm{H} 1$ in mesenchymal stem cells for immune tolerance to cardiac allografts in combination therapy with rapamycin. Transplant Immunol. (2014) 31:65-74. doi: 10.1016/j.trim.2014.06.005

88. Maffioli E, Nonnis S, Angioni R, Santagata F, Calì B, Zanotti L, et al. Proteomic analysis of the secretome of human bone marrowderived mesenchymal stem cells primed by pro-inflammatory cytokines. $J$ Proteomics. (2017) 166:115-26. doi: 10.1016/j.jprot.2017.07.012

89. Nemoto Y, Kanai T, Takahara M, Oshima S, Nakamura T, Okamoto R, et al. Bone marrow-mesenchymal stem cells are a major source of interleukin-7 and sustain colitis by forming the niche for colitogenic CD4 memory T cells. Gut. (2013) 62:1142-52. doi: 10.1136/gutjnl-2012-302029

90. English K, Ryan JM, Tobin L, Murphy MJ, Barry FP, Mahon BP. Cell contact, prostaglandin $\mathrm{E}(2)$ and transforming growth factor beta 1 play non-redundant roles in human mesenchymal stem cell induction of CD4+CD25(High) forkhead box P3+ regulatory T cells. Clin Exp Immunol. (2009) 156:149-60. doi: 10.1111/j.1365-2249.2009.03874.x

91. Negi N, Griffin MD. Effects of mesenchymal stromal cells on regulatory T cells: current understanding and clinical relevance. Stem Cells. (2020) 38:596-605. doi: 10.1002/stem.3151

92. Li H, Zhou R, Wang C, Li Y, Zheng G, Jiang S, et al. T follicular regulatory cells infiltrate the human airways during the onset of acute respiratory distress syndrome and regulate the development of B regulatory cells. Immunol Res. (2018) 66:548-54. doi: 10.1007/s12026-018-9014-7

93. Volchenkov R, Karlsen M, Jonsson R, Appel S. Type 1 regulatory T cells and regulatory B cells induced by tolerogenic dendritic cells. Scand J Immunol. (2013) 77:246-54. doi: 10.1111/sji.12039

94. Fehres CM, van Uden NO, Yeremenko NG, Fernandez L, Franco Salinas G, van Duivenvoorde LM, et al. APRIL induces a novel subset of IgA(+) regulatory b cells that suppress inflammation via expression of IL-10 and PD-L1. Front Immunol. (2019) 10:1368. doi: 10.3389/fimmu.2019.01368

95. Szili D, Bankó Z, Tóth EA, Nagy G, Rojkovich B, Gáti T, et al. TGF $\beta$ activated kinase 1 (TAK1) at the crossroad of B cell receptor and toll-like receptor 9 signaling pathways in human B cells. PLoS ONE. (2014) 9:e96381. doi: 10.1371/journal.pone.0096381

96. Lykken JM, Candando KM, Tedder TF. Regulatory B10 cell development and function. Int Immunol. (2015) 27:471-7. doi: 10.1093/intimm/dxv046

97. Baba Y. Store-operated calcium entry into B cells regulates autoimmune inflammation. Yakugaku Zasshi. (2016) 136:473-8. doi: 10.1248/yakushi.15-00246-3

98. Yu J, Qin B, Moyer AM, Nowsheen S, Tu X, Dong H, et al. Regulation of sister chromatid cohesion by nuclear PD-L1. Cell Res. (2020) 30:590-601. doi: 10.1038/s41422-020-0315-8

99. Ishida Y, Agata Y, Shibahara K, Honjo T. Induced expression of PD-1, a novel member of the immunoglobulin gene superfamily, upon programmed cell death. Embo J. (1992) 11:3887-95. doi: 10.1002/j.1460-2075.1992.tb05481.x

100. Thibult M-L, Mamessier E, Gertner-Dardenne J, Pastor S, JustLandi S, Xerri L, et al. PD-1 is a novel regulator of human B-cell 
activation. Int Immunol. (2012) 25:129-37. doi: 10.1093/intimm/ dxs098

101. Schena F, Gambini C, Gregorio A, Mosconi M, Reverberi D, Gattorno $\mathrm{M}$, et al. Interferon-gamma-dependent inhibition of $\mathrm{B}$ cell activation by bone marrow-derived mesenchymal stem cells in a murine model of systemic lupus erythematosus. Arthritis Rheum. (2010) 62:2776-86. doi: 10.1002/art.27560

102. Phipps RP, Stein SH, Roper RL. A new view of prostaglandin E regulation of the immune response. Immunol Today. (1991) 12:349-52. doi: 10.1016/0167-5699(91)90064-Z

103. Kalinski P. Regulation of immune responses by prostaglandin E2. J Immunol. (2012) 188:21-8. doi: 10.4049/jimmunol.1101029

104. Németh K, Leelahavanichkul A, Yuen PS, Mayer B, Parmelee A, Doi $\mathrm{K}$, et al. Bone marrow stromal cells attenuate sepsis via prostaglandin $\mathrm{E}(2)$-dependent reprogramming of host macrophages to increase their interleukin-10 production. Nat Med. (2009) 15:42-9. doi: 10.1038/nm.1905

105. Mao YX, Xu JF, Seeley EJ, Tang XD, Xu LL, Zhu YG, et al. Adipose tissuederived mesenchymal stem cells attenuate pulmonary infection caused by pseudomonas aeruginosa via inhibiting overproduction of prostaglandin E2. Stem Cells. (2015) 33:2331-42. doi: 10.1002/stem.1996

106. Hsu WT, Lin CH, Chiang BL, Jui HY, Wu KK, Lee CM. Prostaglandin E2 potentiates mesenchymal stem cell-induced IL- $10+$ IFN- $\gamma+$ CD $4+$ regulatory $\mathrm{T}$ cells to control transplant arteriosclerosis. J Immunol. (2013) 190:2372-80. doi: 10.4049/jimmunol.1202996

107. Shin T-H, Lee B-C, Choi SW, Shin J-H, Kang I, Lee JY, et al. Human adipose tissue-derived mesenchymal stem cells alleviate atopic dermatitis via regulation of B lymphocyte maturation. Oncotarget. (2017) 8:512-22. doi: 10.18632/oncotarget.13473

108. Chen R, Cao Y, Tian Y, Gu Y, Lu H, Zhang S, et al. PGE2 ameliorated viral myocarditis development and promoted IL-10-producing regulatory $\mathrm{B}$ cell expansion via MAPKs/AKT-AP1 axis or AhR signaling. Cell Immunol. (2020) 347:104025. doi: 10.1016/j.cellimm.2019.104025

109. Frumento G, Rotondo R, Tonetti M, Damonte G, Benatti U, Ferrara GB. Tryptophan-derived catabolites are responsible for inhibition of $\mathrm{T}$ and natural killer cell proliferation induced by indoleamine 2,3-dioxygenase. $J$ Exp Med. (2002) 196:459-68. doi: 10.1084/jem.20020121

110. DiNatale BC, Murray IA, Schroeder JC, Flaveny CA, Lahoti TS, Laurenzana EM, et al. Kynurenic acid is a potent endogenous aryl hydrocarbon receptor ligand that synergistically induces interleukin-6 in the presence of inflammatory signaling. Toxicol Sci. (2010) 115:89-97. doi: 10.1093/toxsci/kfq024

111. Wang G, Cao K, Liu K, Xue Y, Roberts AI, Li F, et al. Kynurenic acid, an IDO metabolite, controls TSG-6-mediated immunosuppression of human mesenchymal stem cells. Cell Death Differ. (2018) 25:1209-23. doi: 10.1038/s41418-017-0006-2

112. Mounayar M, Kefaloyianni E, Smith B, Solhjou Z, Maarouf OH, Azzi J, et al. PI3k $\alpha$ and STAT1 interplay regulates human mesenchymal stem cell immune polarization. Stem Cells. (2015) 33:1892-901. doi: 10.1002/stem.1986

113. Krampera M, Cosmi L, Angeli R, Pasini A, Liotta F, Andreini A, et al. Role for interferon-gamma in the immunomodulatory activity of human bone marrow mesenchymal stem cells. Stem Cells. (2006) 24:386-98. doi: 10.1634/stemcells.2005-0008

114. Yan Y, Zhao N, He X, Guo H, Zhang Z, Liu T. Mesenchymal stem cell expression of interleukin-35 protects against ulcerative colitis by suppressing mucosal immune responses. Cytotherapy. (2018) 20:911-8. doi: 10.1016/j.jcyt.2018.05.004

115. Sakkas LI, Mavropoulos A, Perricone C, Bogdanos DP. IL-35: a new immunomodulator in autoimmune rheumatic diseases. Immunol Res. (2018) 66:305-12. doi: 10.1007/s12026-018-8998-3

116. Li X, Mai J, Virtue A, Yin Y, Gong R, Sha X, et al. IL-35 is a novel responsive anti-inflammatory cytokine-a new system of categorizing anti-inflammatory cytokines. PLoS ONE. (2012) 7:e33628. doi: 10.1371/journal.pone. 0033628

117. Huang A, Cheng L, He M, Nie J, Wang J, Jiang K. Interleukin-35 on $\mathrm{B}$ cell and $\mathrm{T}$ cell induction and regulation. J Inflamm. (2017) 14:16. doi: 10.1186/s12950-017-0164-5

118. Ceradini DJ, Kulkarni AR, Callaghan MJ, Tepper OM, Bastidas N, Kleinman ME, et al. Progenitor cell trafficking is regulated by hypoxic gradients through HIF-1 induction of SDF-1. Nat Med. (2004) 10:858-64. doi: $10.1038 / \mathrm{nm} 1075$

119. Liu H, Liu S, Li Y, Wang X, Xue W, Ge G, et al. The role of SDF-1CXCR4/CXCR7 axis in the therapeutic effects of hypoxia-preconditioned mesenchymal stem cells for renal ischemia/reperfusion injury. PLoS ONE. (2012) 7:e34608. doi: 10.1371/journal.pone.0034608

120. Humpert M-L, Pinto D, Jarrossay D, Thelen M. CXCR7 influences the migration of B cells during maturation. Eur J Immunol. (2014) 44:694-705. doi: 10.1002/eji.201343907

121. Qin Y, Zhou Z, Zhang F, Wang Y, Shen B, Liu Y, et al. Induction of regulatory B-cells by mesenchymal stem cells is affected by SDF-1 $\alpha$-CXCR7. Cell Physiol Biochem. (2015) 37:117-30. doi: 10.1159/000430338

122. Lan X, Wang G, Xu X, Lu S, Li X, Zhang B, et al. Stromal cell-derived factor-1 mediates cardiac allograft tolerance induced by human endometrial regenerative cell-based therapy. Stem Cells Transl Med. (2017) 6:1997-2008. doi: 10.1002/sctm.17-0091

123. Rickert RC, Jellusova J, Miletic AV. Signaling by the tumor necrosis factor receptor superfamily in B-cell biology and disease. Immunol Rev. (2011) 244:115-33. doi: 10.1111/j.1600-065X.2011.01067.x

124. Chu VT, Enghard P, Riemekasten G, Berek C. In vitro and in vivo activation induces BAFF and APRIL expression in B cells. J Immunol. (2007) 179:594757. doi: 10.4049/jimmunol.179.9.5947

125. Walters S, Webster KE, Sutherland A, Gardam S, Groom J, Liuwantara $\mathrm{D}$, et al. Increased CD4+Foxp3+ $\mathrm{T}$ cells in BAFF-transgenic mice suppress T cell effector responses. J Immunol. (2009) 182:793-801. doi: 10.4049/jimmunol.182.2.793

126. Yang M, Sun L, Wang S, Ko KH, Xu H, Zheng BJ, et al. Novel function of B cell-activating factor in the induction of IL-10-producing regulatory B cells. J Immunol. (2010) 184:3321-5. doi: 10.4049/jimmunol.0902551

127. Dallos T, Krivosíková M, Chorazy-Massalska M, Warnawin E, Zánová E, Rudnicka W, et al. BAFF from bone marrow-derived mesenchymal stromal cells of rheumatoid arthritis patients improves their B-cell viabilitysupporting properties. Folia Biol. (2009) 55:166-76.

128. Peng Y, Chen X, Liu Q, Xu D, Zheng H, Liu L, et al. Alteration of naïve and memory B-cell subset in chronic graft-versus-host disease patients after treatment with mesenchymal stromal cells. Stem Cell Transl Med. (2014) 3:1023-31. doi: 10.5966/sctm.2014-0001

129. Gowhari Shabgah A, Shariati-Sarabi Z, Tavakkol-Afshari J, Ghasemi A, Ghoryani M, Mohammadi M. A significant decrease of BAFF, APRIL, and BAFF receptors following mesenchymal stem cell transplantation in patients with refractory rheumatoid arthritis. Gene. (2020) 732:144336. doi: 10.1016/j.gene.2020.144336

130. Lener T, Gimona M, Aigner L, Borger V, Buzas E, Camussi G, et al. Applying extracellular vesicles based therapeutics in clinical trials - an ISEV position paper. J Extracell Vesicles. (2015) 4:30087. doi: 10.3402/jev.v4. 30087

131. Phinney DG, Pittenger MF. Concise review: MSC-derived exosomes for cell-free therapy. Stem Cells. (2017) 35:851-8. doi: 10.1002/stem.2575

132. Borger V, Bremer M, Ferrer-Tur R, Gockeln L, Stambouli O, Becic A, et al. Mesenchymal stem/stromal cell-derived extracellular vesicles and their potential as novel immunomodulatory therapeutic agents. Int J Mol Sci. (2017) 18:1450. doi: 10.3390/ijms18071450

133. David JM, Dominguez C, Hamilton DH, Palena C. The IL-8/IL-8R axis: a double agent in tumor immune resistance. Vaccines. (2016) 4:22. doi: 10.3390/vaccines 4030022

134. Schroder WA, Major L, Suhrbier A. The role of SerpinB2 in immunity. Crit Rev Immunol. (2011) 31:15-30. doi: 10.1615/CritRevImmunol.v31.i1.20

135. Flach H, Rosenbaum M, Duchniewicz M, Kim S, Zhang SL, Cahalan MD, et al. Mzb1 protein regulates calcium homeostasis, antibody secretion, and integrin activation in innate-like B cells. Immunity. (2010) 33:723-35. doi: 10.1016/j.immuni.2010.11.013

136. Aggarwal S, Pittenger MF. Human mesenchymal stem cells modulate allogeneic immune cell responses. Blood. (2005) 105:1815-22. doi: 10.1182/blood-2004-04-1559

137. Khare D, Or R, Resnick I, Barkatz C, Almogi-Hazan O, Avni B. Mesenchymal stromal cell-derived exosomes affect mRNA expression and function of B-Lymphocytes. Front Immunol. (2018) 9:3053. doi: $10.3389 /$ fimmu.2018.03053 
138. Guo L, Lai P, Wang Y, Huang T, Chen X, Geng S, et al. Extracellular vesicles derived from mesenchymal stem cells prevent skin fibrosis in the cGVHD mouse model by suppressing the activation of macrophages and $\mathrm{B}$ cells immune response. Int Immunopharmacol. (2020) 84:106541. doi: 10.1016/j.intimp.2020.1 06541

139. Xu C, Ren G, Cao G, Chen Q, Shou P, Zheng C, et al. miR-155 regulates immune modulatory properties of mesenchymal stem cells by targeting TAK1-binding protein 2. J Biol Chem. (2013) 288:11074-9. doi: 10.1074/jbc.M112.414862

140. Adamo A, Brandi J, Caligola S, Delfino P, Bazzoni R, Carusone $\mathrm{R}$, et al. Extracellular vesicles mediate mesenchymal stromal celldependent regulation of B cell PI3K-AKT signaling pathway and actin cytoskeleton. Front Immunol. (2019) 10:446. doi: 10.3389/fimmu.2019. 00446
141. Witwer KW, van Balkom BWM, Bruno S, Choo A, Dominici M, Gimona M, et al. Defining mesenchymal stromal cell (MSC)-derived small extracellular vesicles for therapeutic applications. J Extracell Vesicles. (2019) 8:1609206. doi: 10.1080/20013078.2019.1609206

Conflict of Interest: The authors declare that the research was conducted in the absence of any commercial or financial relationships that could be construed as a potential conflict of interest.

Copyright (c) $2020 \mathrm{Liu}$, Liu and Chen. This is an open-access article distributed under the terms of the Creative Commons Attribution License (CC BY). The use, distribution or reproduction in other forums is permitted, provided the original author(s) and the copyright owner(s) are credited and that the original publication in this journal is cited, in accordance with accepted academic practice. No use, distribution or reproduction is permitted which does not comply with these terms. 